Article

\title{
Functional Identification of Salt-Stress-Related Genes Using the FOX Hunting System from Ipomoea pes-caprae
}

\author{
Mei Zhang 1,2,*(1), Hui Zhang ${ }^{1,2,3}$, Jie-Xuan Zheng ${ }^{1,2,3}$, Hui Mo ${ }^{1,2}$, Kuai-Fei Xia ${ }^{1,2}$ and \\ Shu-Guang Jian ${ }^{1, *}$ \\ 1 Key Laboratory of Applied Botany, South China Botanical Garden, Chinese Academy of Sciences, \\ Guangzhou 510650, China; zhanghuir@mails.ucas.ac.cn (H.Z.); zhengjiexuan16@mails.ucas.ac.cn (J.-X.Z.); \\ mohui@scbg.ac.cn (H.M.); xiakuaifei@scbg.ac.cn (K.-F.X.) \\ 2 Key Laboratory of South China Agricultural Plant Molecular Analysis and Genetic Improvement, \\ South China Botanical Garden, Chinese Academy of Sciences, Guangzhou 510650, China \\ 3 University of the Chinese Academy of Sciences, Beijing 100039, China \\ * Correspondence: zhangmei@scbg.ac.cn (M.Z.); jiansg@scbg.ac.cn (S.-G.J.); \\ Tel.: +86-20-3708-3652 (M.Z.); +86-20-3725-2585 (S.-G.J.)
}

Received: 28 July 2018; Accepted: 31 October 2018; Published: 2 November 2018

\begin{abstract}
Ipomoea pes-caprae is a seashore halophytic plant and is therefore a good model for studying the molecular mechanisms underlying salt and stress tolerance in plant research. Here, we performed Full-length cDNA Over-eXpressor (FOX) gene hunting with a functional screening of a cDNA library using a salt-sensitive yeast mutant strain to isolate the salt-stress-related genes of I. pes-caprae (IpSR genes). The library was screened for genes that complemented the salt defect of yeast mutant AXT3 and could grow in the presence of $75 \mathrm{mM} \mathrm{NaCl}$. We obtained 38 candidate salt-stress-related full-length cDNA clones from the I. pes-caprae cDNA library. The genes are predicted to encode proteins involved in water deficit, reactive oxygen species (ROS) scavenging, cellular vesicle trafficking, metabolic enzymes, and signal transduction factors. When combined with the quantitative reverse transcription-polymerase chain reaction (qRT-PCR) analyses, several potential functional salt-tolerance-related genes were emphasized. This approach provides a rapid assay system for the large-scale screening of I. pes-caprae genes involved in the salt stress response and supports the identification of genes responsible for the molecular mechanisms of salt tolerance.
\end{abstract}

Keywords: salt stress; cDNA library; FOX gene hunting system; ROS accumulation; Ipomoea pes-caprae L.

\section{Introduction}

Plants are continuously challenged by multiple stresses in nature and are also subjected to the evolutionary pressures imposed by natural selection. Among diverse adversity stresses, salinity is one of growing problems which affect plant growth and agricultural production, and even result in environmental degradation [1,2]. The mechanisms of salinity tolerance in plants have been classified into three types - ion exclusion, osmotic tolerance, and tissue tolerance [3] —or been summarized as osmotic stress and ionic stress [4]. During the various plant processes, several types of key genes are involved in the plant salinity tolerance, mainly by mediating $\mathrm{Na}^{+} / \mathrm{K}^{+}$absorption, detoxification, and exclusion, and the functional genes mainly include channel proteins, transcription factors, or some metabolic enzymes or protective proteins $[4,5]$.

Based on the adaptability of plants to high salinity, most plants are classified into two categories: glycophytes and halophytes. Compared with glycophytes, halophytes are defined as plants which can naturally survive in a saline environment and even prefer it [6]. Some halophytes that flourish 
in high-salinity conditions are termed as extremophiles [7]. In the course of evolution, halophytes or extremophiles have developed various adaptive mechanisms responding to salinity to ensure their survival and alternation of generations [8]. Research into halophyte stress-tolerance-related genes would improve the understanding of the adaptation of plants to environmental stress and provide a good foundation for formulating effective measures to modify the tolerance of crops to external stresses [1].

Ipomoea pes-caprae (Convolvulaceae) is a perennial herbaceous vine plant distributing mainly on sandy beaches or in sunny positions on the roadside in tropical and subtropical regions, and usually grows in a high-temperature, dry environment, exhibiting great advantages in salt tolerance and drought resistance $[9,10]$. As a typical halophyte plant with a high level of nutrient utilization efficiency, I. pes-caprae constitutes a superior wild plant resource and plays important roles in sand fixation, wind resistance, landscape greening, and ecological restoration of the vegetation in tropical and subtropical coral islands and coastal zones $[9,11]$. In addition, since I. pes-caprae is also a highly adversity-resistant perennial officinal plant with super excellent phenotypes of resistance to abiotic stresses, a molecular biology approach to identification of the stress-tolerant functional genes of this species to extreme environments has great potential for application and significance in plant science.

Salinity is a common abiotic stress that is usually associated with saline/alkali land or sea beaches, and salt accumulation in soil or water can inhibit plant growth and reduce absorption of water, thereby causing osmotic or water-deficit stress in vivo. In both earlier and more recent studies, much research has focused on the "omics" changes induced by external stresses [7,12]. However, due to the lack of genomic information for non-model plant species, the changes in transcriptomic, proteomic, or metabolomic processes caused by stress do not provide sufficient information for the cloning and isolation of stress-related genes in non-model plant species. The Full-length cDNA Over-eXpressor (FOX) gene hunting system is a functional screening method using the overexpression of full-length cDNA libraries in model plants (Arabidopsis or rice) or microorganisms (mainly yeast) [13-17], by which some unknown stress-related genes have been cloned and preliminarily identified. Actually, in much earlier studies, the functional screening work with yeast mutants was widely used to separate salt tolerance genes from plant cDNA libraries due to the lack of any genomic sequence information, even in model plants such as Arabidopsis [18,19], tobacco [20], or rice [21]. Since yeast (Saccharomyces cerevisiae) is a unicellular organism with the best research background, the functional screening of stress-tolerance-related genes in yeast with the FOX gene hunting system seems more simple and easier to operate than in model plants (such as Arabidopsis and rice). In recent years, this gene hunting system has also been widely applied to isolate salt tolerance genes in some extreme halophyte species without any genomic sequence information [15,16,22].

In the present study, we constructed a yeast expression cDNA library and performed functional screening work in order to identify the candidate genes encoding functional proteins involved in salt tolerance in I. pes-caprae. We obtained a preliminary series of candidate genes for increasing the salt tolerance of yeast that can be considered as salt-stress-related functional genes for further research.

\section{Results}

\subsection{The $\mathrm{Na}^{+}$and $\mathrm{K}^{+}$Contents in I. pes-caprae}

Figure 1A shows that the concentration of $\mathrm{Na}^{+}$in different tissues of I. pes-caprae collected from four different beaches (Shanwei, SW; Shenzhen, SZ; Huizhou, HZ; Yangjiang, YJ) and South China Botanical Garden (SCBG) in Guangdong province ranged from 1 to $16 \mathrm{mg} \mathrm{g}^{-1}$ dry weight. In general, the aerial parts of I. pes-caprae (leaves) living in beaches contained high amounts of $\mathrm{Na}^{+}$compared with the underground portion (roots) (Figure 1A), while the SCBG sample did not show this salt-enriched feature. Although the $\mathrm{Na}^{+}$content in the vines appeared to be lower than in the leaves or underground portion, if we consider the great biomass contribution from the vines, we can conclude that the aerial part of I. pes-caprae contained the bulk of the $\mathrm{Na}^{+}$absorbed by the roots from the seawater 
(Figure 2A). As to the $\mathrm{K}^{+}$content, all of the I. pes-caprae samples showed no obvious increase compared with Arabidopsis (Figure 1B), which indicated that the $\mathrm{K}^{+}$might not be the cause of osmotic stress in I. pes-caprae plants in vivo.

A

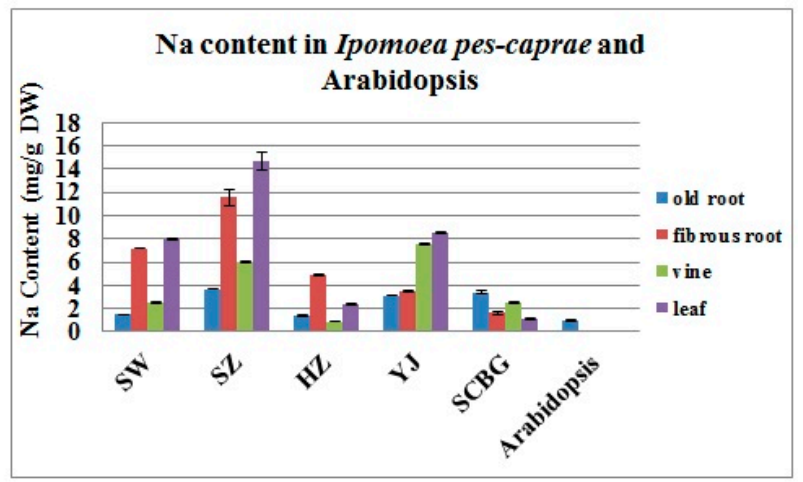

B

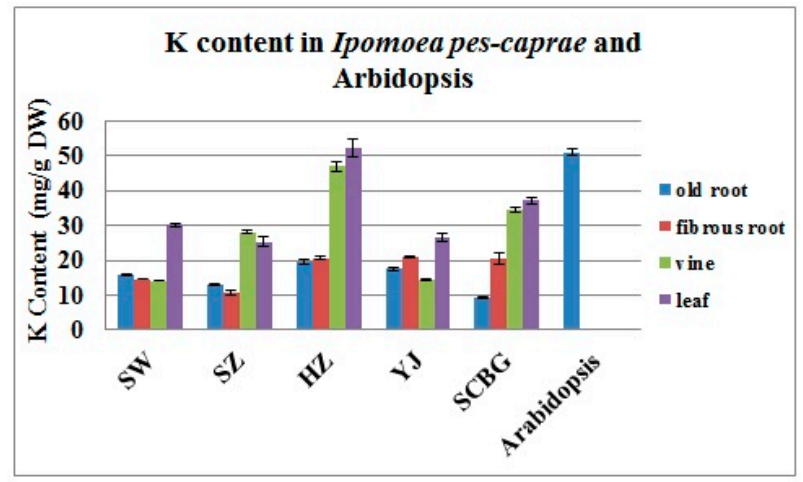

Figure 1. $\mathrm{Na}^{+}(\mathbf{A})$ and $\mathrm{K}^{+}(\mathbf{B})$ contents in I. pes-caprae collected from five different areas in Guangdong province. SW: sample from Shanwei $\left(22^{\circ} 47^{\prime} 10.97^{\prime \prime} \mathrm{N}, 115^{\circ} 10^{\prime} 22.83^{\prime \prime} \mathrm{E}\right)$; SZ: sample from Shenzhen $\left(22^{\circ} 32^{\prime} 13.16^{\prime \prime} \mathrm{N}, 114^{\circ} 29^{\prime} 11.26^{\prime \prime} \mathrm{E}\right)$; HZ: sample from Huizhou $\left(22^{\circ} 41^{\prime} 24.81^{\prime \prime} \mathrm{N}, 114^{\circ} 44^{\prime} 48.02^{\prime \prime} \mathrm{E}\right)$; YJ: sample from Yangjiang ( $\left.21^{\circ} 34^{\prime} 37.34^{\prime \prime} \mathrm{N}, 111^{\circ} 52^{\prime} 15.95^{\prime \prime} \mathrm{E}\right)$; SCBG: sample from South China Botanical Garden $\left(23^{\circ} 18^{\prime} 49.89^{\prime \prime} \mathrm{N}, 113^{\circ} 35^{\prime} 84.32^{\prime \prime} \mathrm{E}\right)$. An Arabidopsis sample is also shown as a glycophyte control. All experiments were carried out for three replicates. The results shown are the mean $\pm \mathrm{SD}(n=3)$.

Overall, compared with regular glycophytes such as Arabidopsis (Figure 1A), the $\mathrm{Na}^{+}$contents in living plants of I. pes-caprae are much higher, which indicated that I. pes-caprae can accumulate a large amount of saline ions in vivo and has evolved a series of salt-tolerant mechanisms as an adaptive response to high-salt environments in order to lessen or even eliminate osmotic stress and the toxic ions from seawater. Additionally, osmotic stress damage is reduced by the waxy leaf surface and succulency. The vines of I. pes-caprae easily sprout adventitious roots, and the depth of primary roots can reach 3 meters, to make sure the plant gets water with little problem [23]. The above features indicate that I. pes-caprae can easily absorb water and limit the stomata transpiration, and thus possess strong drought tolerance under high temperature and strong light irradiation.

\subsection{Construction of the cDNA Expression Library}

An investigation of the habitat of I. pes-caprae revealed that it is a halophyte and is therefore associated with high salt tolerance (Figure 2A). For the purpose of isolating genes involved in salt tolerance in I. pes-caprae, a cDNA library was constructed with Gateway technology. Total RNA was separated from mixed samples of actively growing leaves, shoots, and roots of I. pes-caprae. The final amount of RNA was $842 \mu \mathrm{g}$ with a concentration of $0.9351 \mu \mathrm{g} \mu \mathrm{L}^{-1}$ and A260/280 and A260/230 
values for total RNA of 2.17 and 2.35, respectively. The total RNA had good quality with an RIN (RNA integrity number) value of 7.7. Subsequently, the mRNA was purified by magnetic beads and reached a final amount of $5 \mu \mathrm{g}$. In brief, by agarose gel electrophoresis, the total RNA and mRNA exhibited excellent quality for cDNA library construction (Figure 2B,C).

The cDNA entry library and pYES-DEST52 expression library were evaluated by counting the CFUs (colony-forming units). Generally, totals of $6.08 \times 10^{6}$ and $5.48 \times 10^{6}$ clones were contained in the entry library and expression library, respectively, which was sufficient to represent most of the genes expressed in I. pes-caprae. Meanwhile, the PCR insert fragment of 24 randomly picked clones from the entry library and expression library ranged from 0.5 to $3.0 \mathrm{~kb}$ with an average size over $1 \mathrm{~kb}$ (Figure 2D,E). Furthermore, 50 random clones from the pYES-DEST52 expression library were sequenced for full-length identification. After removing eight indistinguishable sequences, the ORFfinder program (available online: https:/ /www.ncbi.nlm.nih.gov/orffinder/) was used to identify the longest open reading frames (ORFs) of the remaining 42 clones, and then the SmartBLAST analysis with the longest ORFs showed that some cDNAs were full-length and some were partial (Supplementary Data Table S1). Each possessed the ATG start codon (Supplementary Data Table S2), which indicated that the expression of cDNAs was guaranteed in the yeast and that the functional screening was effective. The sequences of these cDNA are listed in Supplementary Data Table S3.

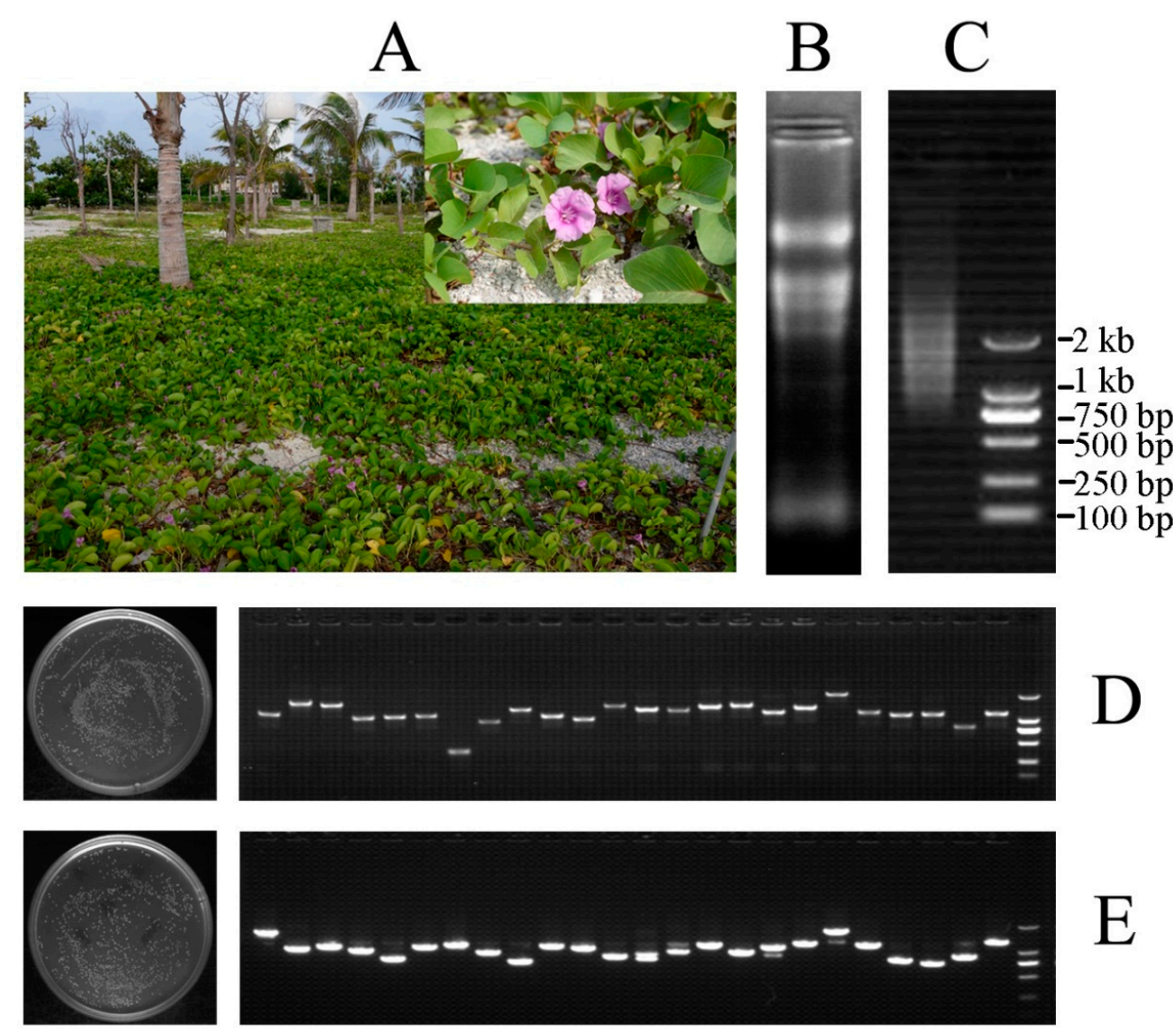

Figure 2. (A) The habitats of I. pes-caprae. This pictures were taken at the beach of Zhaoshu Island $\left(16^{\circ} 58^{\prime} \mathrm{N}, 112^{\circ} 16^{\prime} \mathrm{E}\right)$ on 23 August 2016; (B) Analysis and detection of total RNA extracted from I. pes-caprae by $1 \%$ agarose gel electrophoresis; (C) Analysis and detection of mRNA purified from total RNA extracted from I. pes-caprae by $1 \%$ agarose gel electrophoresis; (D) Titer and inserted fragment detection of the entry cDNA library by colony PCR; (E) Titer and inserted fragment detection of the expression cDNA library by colony PCR.

\subsection{Functional Screening of the cDNA Library for Mining the Candidate IpSR Genes}

In this investigation, we chose a salt sensitive yeast strain, AXT3, to perform the FOX hunting assay of the I. pes-caprae cDNA library. AXT3 is functional knock-out with three $\mathrm{Na}^{+}$transporter 
genes (ena1-4, nha1, and $n h x 1$ ) and cannot grow well when the $\mathrm{Na}^{+}$concentration in medium is above $50 \mathrm{mM}[24,25]$. From initial screening of the library plasmids, we chose $75 \mathrm{mM} \mathrm{NaCl}$ as a stringent selection concentration, with the empty expression vector pYES2 as a negative control. We found that under the challenge of $75 \mathrm{mM} \mathrm{NaCl}$, the AXT3 yeast transformed with pYES2 could not grow into single clones on an SDG-Ura (supplied with adenine) plate, and a series of rescued single clones transformed with the library plasmids could be picked out and analyzed.

In brief, the plasmids ( $2-5 \mu \mathrm{g}$ in total) of the pYES-DEST52 expression library were introduced into salt-sensitive AXT3 competent cells. A total of about 100 single yeast clones were obtained that could grow on NaCl-containing SDG-Ura medium $(75 \mathrm{mM} \mathrm{NaCl})$. These yeast clones were selected and amplified, and then the obtained plasmids were identified by alkali splitting and amplified in $E$ coli. The single clone was selected and sequenced. After deleting some noncoding RNA sequences and poor-quality (including partials) or nonreferenced sequences, we ultimately acquired 38 meaningful reference recombinant clones encoding full-length cDNAs of I. pes-caprae genes. Finally, these 38 cDNAs were considered as candidate salt-stress-related genes in I. pes-caprae (IpSRs, Table 1). The sequences of these cDNA are listed in Supplementary Data Table S4.

Table 1. Annotation of 38 full-length IpSRs obtained from the yeast functional screening assay.

\begin{tabular}{|c|c|c|c|}
\hline Clone & GenBank Accession No. & Functional Annotation & $\begin{array}{l}\text { Length of cDNAs and Proteins } \\
\text { Encoded by the Longest ORFs }\end{array}$ \\
\hline IpSR1 (IpASR) & MF680587 & $\begin{array}{l}\text { putative ripening protein, abscisic acid, stress, and } \\
\text { ripening-induced protein (ASR) }\end{array}$ & $962 \mathrm{bp}, 215$ aa \\
\hline IpSR2 (IpATPD) & MF680588 & ATP synthase delta chain, chloroplastic & $921 \mathrm{bp}, 250$ aa \\
\hline IpSR3 (IpNUD) & MF680589 & nudix hydrolase, chloroplastic & 769 bp, 168 aa \\
\hline IpSR4 (IpTSJT1-1) & MF680590 & stem-specific protein TSJT1-like & $1260 \mathrm{bp}, 251$ aa \\
\hline IpSR5 (IpCDI) & MF680591 & contact-dependent growth inhibition (CDI)-like protein & $1262 \mathrm{bp}, 277$ aa \\
\hline IpSR6 (IpFBP) & MF680592 & F-box protein At5g46170-like & $1538 \mathrm{bp}, 388$ aa \\
\hline IpSR7 (IpCAB21) & MF680593 & chlorophyll a-b binding protein 21 , chloroplastic & $1013 \mathrm{bp}, 267$ aa \\
\hline IpSR8 (IpERVT) & MF680594 & endoplasmic reticulum vesicle transporter, C-terminal & $1428 \mathrm{bp}, 386$ aа \\
\hline IpSR9 (IpTSJT1-2) & MF680595 & stem-specific protein TSJT1-like & $1196 \mathrm{bp}, 237$ aа \\
\hline IpSR10 (IpPI1) & MF680596 & probable proteasome inhibitor & $1115 \mathrm{bp}, 343$ aa \\
\hline IpSR11 (IpFRK) & MF680597 & fructokinase & $1312 \mathrm{bp}, 324$ aa \\
\hline IpSR12 (IpPABP) & MF680598 & polyadenylate-binding protein $\mathrm{RBP} 47 \mathrm{~B}^{\prime}$ isoform $\mathrm{X} 1$ & $1598 \mathrm{bp}, 423$ aa \\
\hline IpSR13 (IpTC) & MF680599 & probable tocopherol cyclase, chloroplastic & $2007 \mathrm{bp}, 487$ aa \\
\hline IpSR14 (IpSNARE) & MF680600 & hypothetical protein, Syntaxin/t-SNARE family protein & $1743 \mathrm{bp}, 346$ aa \\
\hline IpSR15 (IpPT) & MF680601 & probable inorganic phosphate transporter 1-3 & 1918 bp, 540 aа \\
\hline IpSR16 (IpAHCY) & MF680602 & adenosylhomocysteinase 1 & $1844 \mathrm{bp}, 485$ aа \\
\hline IpSR17 (IpPUP) & MF680603 & peptide upstream protein & $2123 \mathrm{bp}, 453$ aa \\
\hline IpSR18 (IpCAT) & MF680604 & catalase & $1758 \mathrm{bp}, 492$ aa \\
\hline IpSR19 (IpSRP) & MF680605 & stress responsive alpha-beta barrel domain protein & $847 \mathrm{bp}, 221$ aa \\
\hline IpSR20 (IpRPB7) & MF680606 & DNA-directed RNA polymerase II subunit RPB7 & $976 \mathrm{bp}, 177$ aa \\
\hline IpSR21 (IpUSP3) & MF680607 & ubiquitin carboxyl-terminal hydrolase 3 & $1536 \mathrm{bp}, 368$ aa \\
\hline IpSR22 (IpRPS25) & MF680608 & 40 S ribosomal protein $\mathrm{S} 25$ & $557 \mathrm{bp}, 108$ aa \\
\hline IpSR23 (IpPI2) & MF680609 & probable proteasome inhibitor & $1116 \mathrm{bp}, 300$ aа \\
\hline IpSR24 (IpHP1) & MF680610 & hypothetical protein AT3G52710 & 997 bp, 225 aa \\
\hline IpSR25 (IpPMM) & MF680611 & phosphomannomutase & 1048 bp, 246 aa \\
\hline IpSR26 (IpLEA) & MF680612 & desiccation-related protein At2g46140 & 1392 bp, 313 aa \\
\hline IpSR27 (IpLRRK) & MF680613 & protein kinase superfamily protein & $1732 \mathrm{bp}, 385$ aa \\
\hline IpSR28 (IpDNAJ) & MF765747 & dnaj protein-like protein & $1595 \mathrm{bp}, 428$ aа \\
\hline IpSR29 (IpPSK) & MF680614 & phytosulfokines-like & $721 \mathrm{bp}, 81$ aa \\
\hline IpSR30 (IpPSCXI) & MF680615 & photosystem I reaction center subunit XI, chloroplastic & 803 bp, 218 aa \\
\hline IpSR31 (IpSCP) & MF680616 & sugar carrier protein $C$ & $1877 \mathrm{bp}, 528$ aа \\
\hline IpSR32 (IpHRGP) & MF680617 & hydroxyproline-rich glycoprotein family protein & $930 \mathrm{bp}, 215$ aa \\
\hline IpSR33 (IpGST) & MF680618 & glutathione S-transferase L3-like isoform X1 & $1022 \mathrm{bp}, 234$ aa \\
\hline IpSR34 (IpABAH) & MF680619 & abscisic acid $8^{\prime}$-hydroxylase 4 & $1748 \mathrm{bp}, 465$ aа \\
\hline IpSR35 (IpSR45a) & MF680620 & serine/arginine-rich splicing factor SR45a isoform X2 & $1106 \mathrm{bp}, 243$ aа \\
\hline IpSR36 (IpFMT) & MF680621 & quercetin 3-O-methyltransferase 1 & $1277 \mathrm{bp}, 356$ aa \\
\hline IpSR37 (IpGBP) & MF680622 & guanine nucleotide-binding protein subunit beta-like protein & $1253 \mathrm{bp}, 326$ aa \\
\hline IpSR38 (IpDHN) & KX426069 & dehydrin & $983 \mathrm{bp}, 217$ aа \\
\hline
\end{tabular}




\subsection{Retransformation and Salt Tolerance Confirmation in Yeast}

To avoid or prevent false positive results during the library screening process, and also to eliminate the possibility that one yeast clone might carry multiple genes, the plasmids carrying different IpSRs were reintroduced into the yeast strain AXT3 and its allele wild-type W303 to further confirm that these IpSRs could increase the salt tolerance of yeast.

As observed from Figure 3, all 38 genes showed increased salt tolerance in the yeast mutant strain AXT3 under different $\mathrm{NaCl}$ concentrations. At the $50 \mathrm{mM} \mathrm{NaCl}$ level, all 38 IpSRs almost recovered the salt sensitivity of AXT3, and all the transformant yeast clones showed recovered growth in comparison to the control AXT3 transformed with the empty vector, pYES2. Meanwhile, at higher NaCl levels (75 mM and $200 \mathrm{mM}$ ), the 38 IpSRs elevated the salt tolerance of AXT3 to some extent compared with the control AXT3.
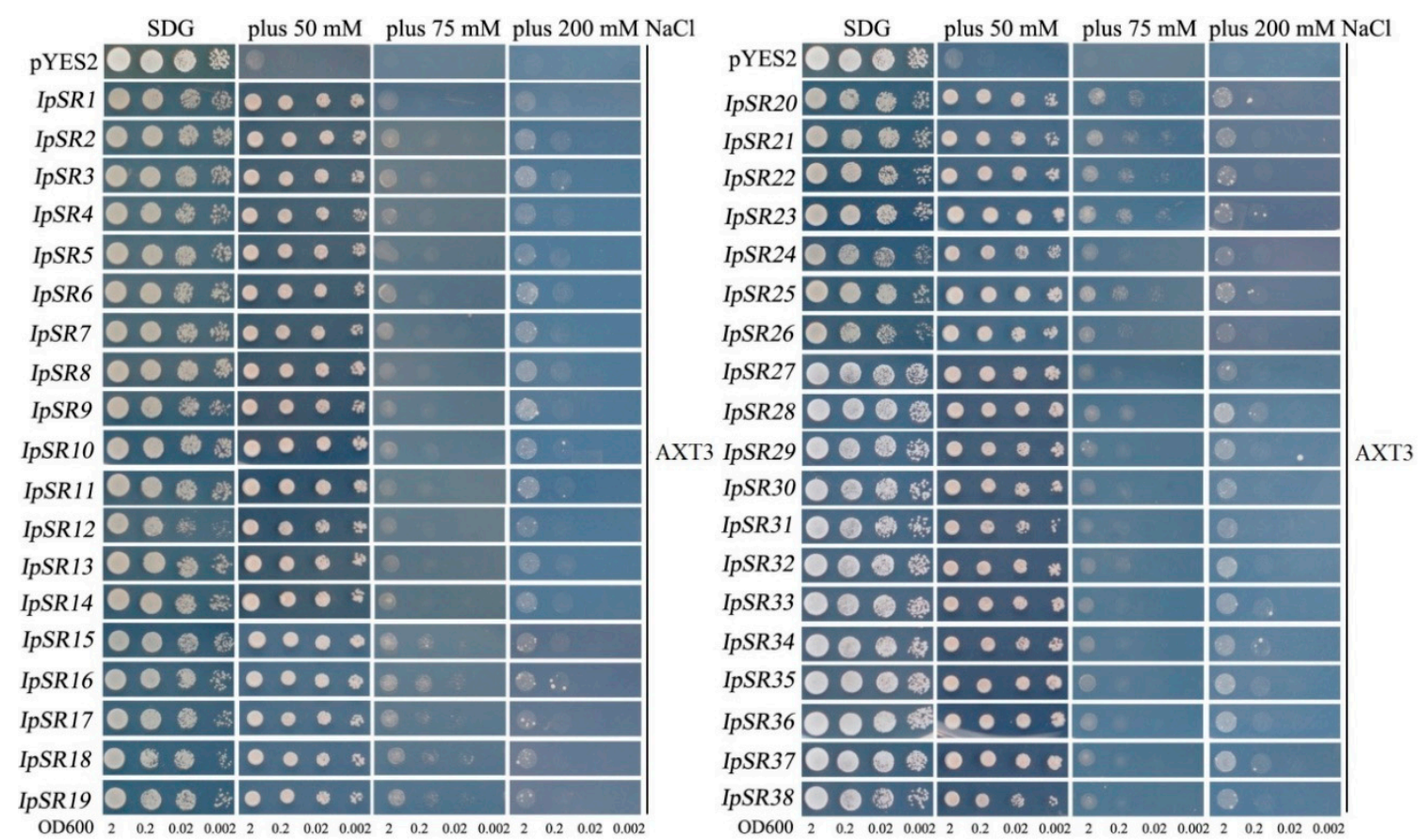

Figure 3. Salinity-tolerance confirmations in the yeast salt-sensitive mutant AXT3 of 38 clones (IpSR1 to 38) via library screening from I. pes-caprae. The yeast cultures (OD600 to 2) were serially diluted to OD600 values of $0.2,0.02$, and 0.002 , and then $2 \mu \mathrm{L}$ of yeast liquid was spotted onto SDG-Ura (supplied with adenine for AXT3) plates with or without $\mathrm{NaCl}(0,50,75$, and $200 \mathrm{mM} \mathrm{NaCl}$ ) for 5-10 days. The empty vector pYES2 represents the negative control.

We also performed this assay in the wild-type yeast strain W303. As shown in Figure 4, the results showed that in the W303 carrying salt tolerance genes, the 38 IpSRs grew better than those with the empty vector pYES2 in the medium containing $0.85 \mathrm{M}, 1.28 \mathrm{M}$, and $1.5 \mathrm{M} \mathrm{NaCl}$, while no difference was observed in the growth of all yeast in the media lacking salt. These results further demonstrated the salt tolerance function of the 38 candidate genes from I. pes-caprae in yeast. 

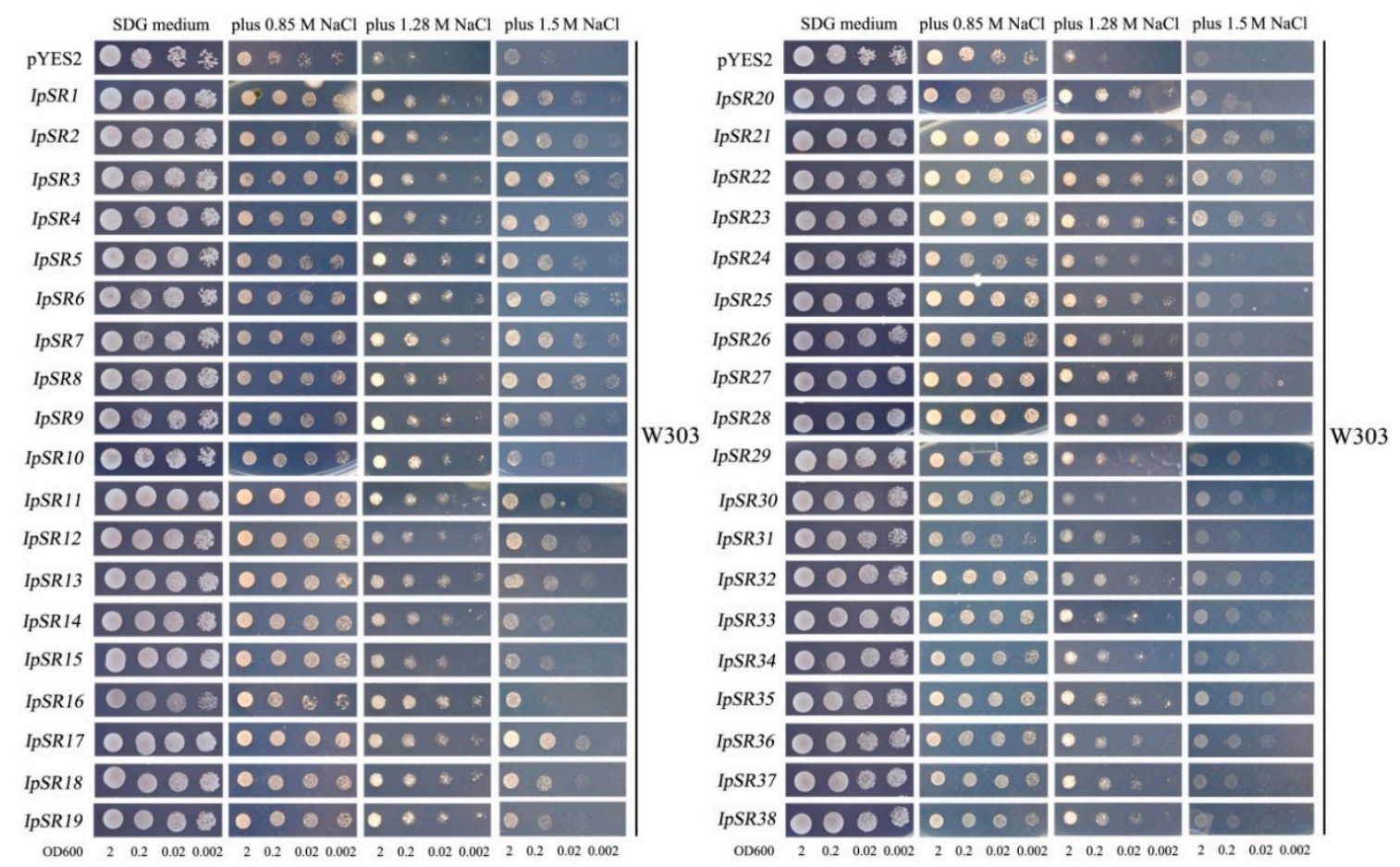

Figure 4. Salinity-tolerance confirmations in yeast wild-type strain W303 of 38 clones (IpSR1 to 38) via library screening from I. pes-caprae. The yeast culture (OD600 to 2) was serially diluted to OD600 values of $0.2,0.02$, and 0.002 , and then $2 \mu \mathrm{L}$ of yeast liquid was spotted onto SDG-Ura (supplied with adenine/leucine/histidine/tryptophan for W303) plates with $(0.85,1.28$, and $1.5 \mathrm{M} \mathrm{NaCl})$ or without

$\mathrm{NaCl}$ for $5-10$ days at $30^{\circ} \mathrm{C}$. The empty vector pYES2 represents negative control.

\section{5. $\mathrm{H}_{2} \mathrm{O}_{2}$ Sensitivity Assays in Yeast}

In plants, salt challenge causes osmotic disruption, which in turn leads to ROS production [6]; therefore, oxidant stress pathways might be involved in the salt tolerance pathway. In our research, we assessed the antioxidative activities of some IpSR genes, including IpSR1 (ABA/water stress/ ripening-induced, IpASR), IpSR14 (syntaxin/t-SNARE family protein, IpSNARE), IpSR18 (catalase, IpCAT), IpSR19 (stress responsive alpha-beta barrel domain protein, IpSRP), IpSR26 (late embryogenesis abundant protein, I LEEA), IpSR33 (glutathione S-transferase, IpGST), and IpSR38 (dehydrin, I $D H H N$ ). Recombinant plasmids pYES-DEST52 carrying the above IpSR cDNAs were introduced into yeast $\mathrm{H}_{2} \mathrm{O}_{2}$-sensitive mutants yap $1 \Delta$ and $s k n 7 \Delta$. The yeast genes $Y A P 1$ and $S K N 7$ encode two transcriptional factors that play regulatory roles in oxidative stress [26], and mutations of these two genes will result in a decrease in oxidation resistance, exhibiting a sensitive phenotype to $\mathrm{H}_{2} \mathrm{O}_{2}$. Our results showed that the above-mentioned seven IpSR genes all elevated the tolerance to $\mathrm{H}_{2} \mathrm{O}_{2}$ of transformed yeast (yap $1 \Delta$ and $s k n 7 \Delta$ ). This indicates that the products encoded by these IpSR genes all possess some antioxidative activities (Figure 5A,B).

\section{6. qRT-PCR Analysis of Candidate Genes under Salt and Osmotic Stress}

In addition to the biochemical functions of the IpSR proteins expressed in yeast, the transcriptional changes of IpSRs in I. pes-caprae also reflect their biological roles under stress treatments. Therefore, we performed qRT-PCR analysis of 38 genes from desiccation- or osmotic-stressed I. pes-caprae (Figure 6; Supplementary Data Figures S1 and S2). We focused here on the induced expression of some IpSRs. In general, the seven IpSR genes whose products possess antioxidant activities in yeast, including IpSR1, IpSR14, IpSR18, IpSR19, IpSR26, IpSR33, and IpSR38, all without exception exhibited obvious characteristics of induced expression under both salt and osmotic stress (Figure 6). Furthermore, in the other 31 candidate IpSRs, eight genes showed significantly 
induced patterns under these two water imbalance stresses, including IpSR2 (ATP synthase delta chain), IpSR4 (stem-specific protein TSJT1-like protein), IpSR8 (endoplasmic reticulum vesicle transporter), IpSR11 (fructokinase), IpSR16 (adenosylhomocysteinase 1), IpSR24 (hypothetical protein AT3G52710), IpSR25 (phosphomannomutase), and IpSR27 (probable leucine-rich repeat receptor-like serine/threonine-protein kinase At1g56140). There were also three IpSRs, including IpSR9 (stem-specific protein TSJT1-like), IpSR20 (DNA-directed RNA polymerase II subunit RPB7), and IpSR29 (phytosulfokines-like) that showed decreased expression patterns under both treatments. Some IpSR genes only showed obvious salt-inducible expression patterns (IpSR10, IpSR12, IpSR15, IpSR23, IpSR32, and IpSR35) or obvious osmotic-inducible expression patterns (IpSR21 and IpSR27) (Supplementary Data Figures S1 and S2).

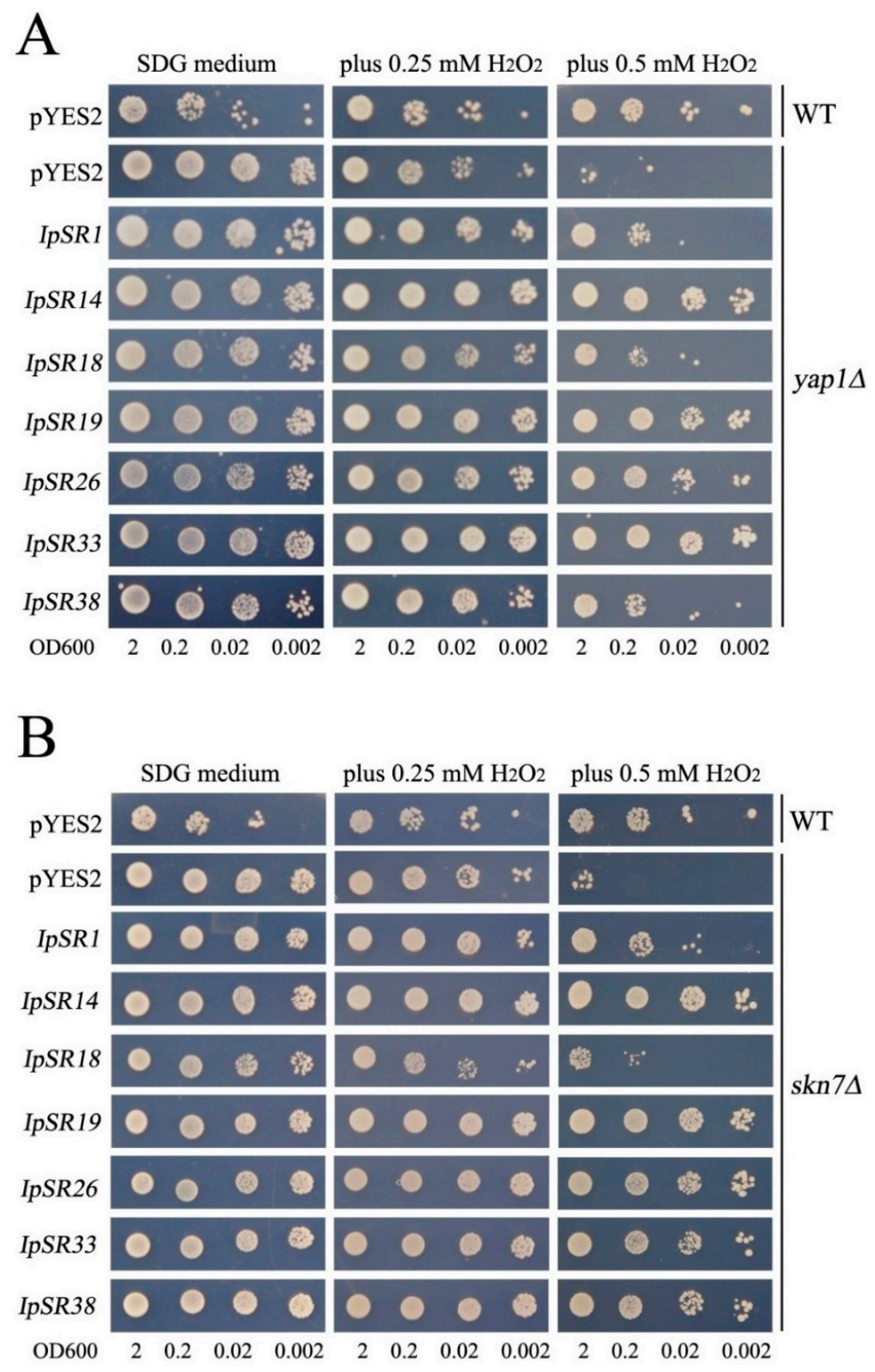

Figure 5. The oxidative resistance test of seven IpSR cDNAs (IpSR1, IpSR14, IpSR18, IpSR19, IpSR26, IpSR33, and IpSR38) overexpressed in the yeast mutant yap1 $\Delta$ (A) and $s k n 7 \Delta$ (B). The yeast culture (OD600 to 2) was serially diluted to OD600 values of $0.2,0.02$, and 0.002 , and then $2 \mu \mathrm{L}$ of yeast liquid was spotted onto SDG-Ura plates without or with $\mathrm{H}_{2} \mathrm{O}_{2}(0.25 \mathrm{mM}$ and $0.5 \mathrm{mM})$ for 5-10 days at $30{ }^{\circ} \mathrm{C}$. As a negative control, the mutant strain yap1 $\Delta$ was transformed with the empty vector pYES2. As a positive control, wild-type yeast BY4741 (WT) was transformed with the empty vector pYES2. 


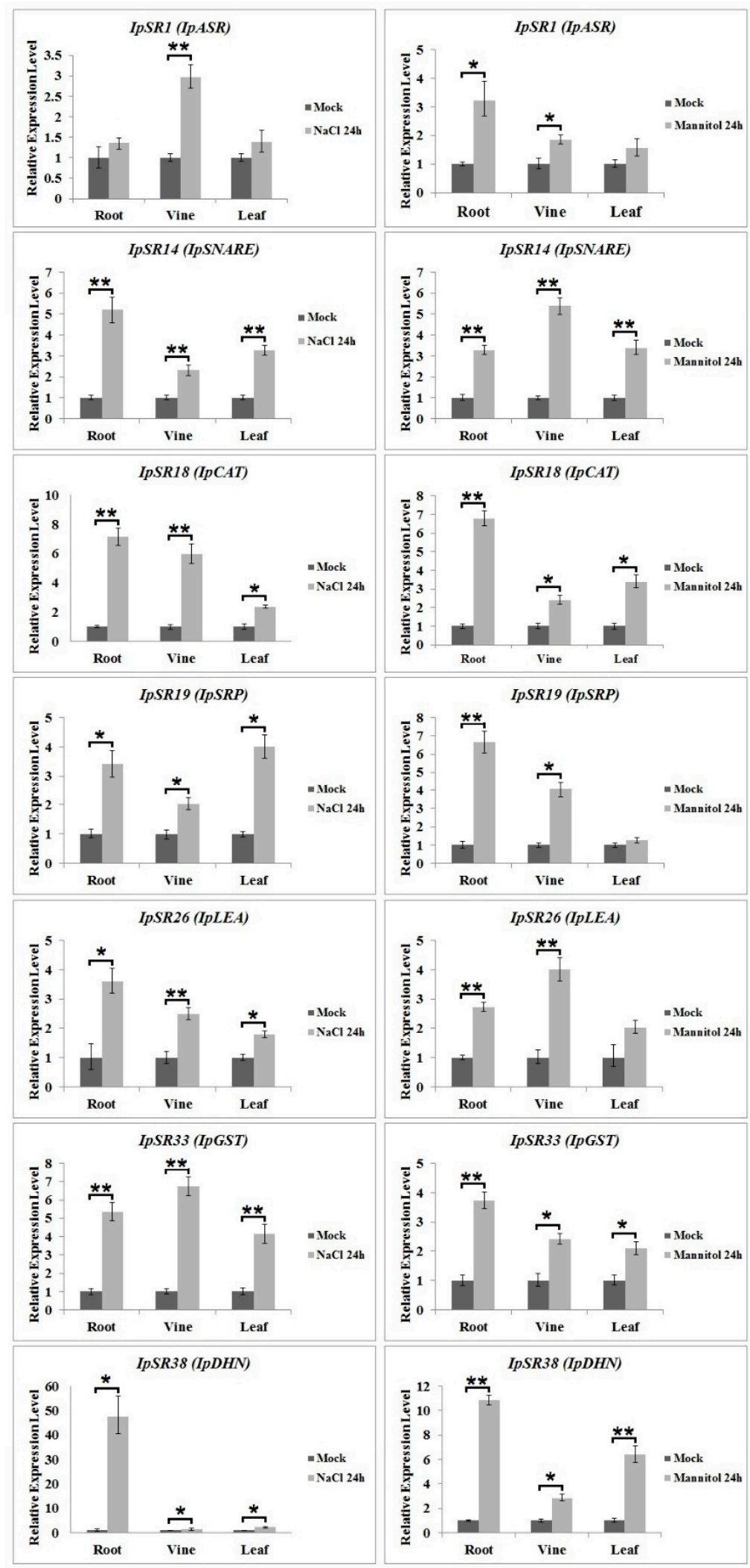

Figure 6. RT-PCR analyses of seven salinity-tolerant candidate genes (IpSR1, IpSR14, IpSR18, IpSR19, $I p S R 26, I p S R 33$, and IpSR38) in the roots, vines, and leaves of I. pes-caprae seedlings under salinity (left, $300 \mathrm{mM} \mathrm{NaCl}$ ) and osmotic (right, $300 \mathrm{mM}$ mannitol) stresses at 0 and $24 \mathrm{~h}$. The house-keeping gene IpUBQ (GenBank accession number: MF502417) was used as a reference gene. All determinations were carried out for three biological replicates. The results shown are the mean $\pm \operatorname{SD}(n \geq 3)$. * and ** indicate significant differences in comparison with the wild type at $0.01<p<0.05$ and $p<0.01$, respectively (Student's $t$-test). 


\section{Discussion}

Halophytes are considered to be the best germplasms for saline agriculture since they possess a strong capacity to thrive under extremely saline conditions [27]. Most crops are glycophytes; therefore, identifying the genes responsible for superior salinity tolerance in halophytes has great potential for the development of salinity-tolerant glycophytes, especially for the genetic modification of crops to improve salt tolerance. To characterize the genes involved in the salt stress response in I. pes-caprae, we screened the cDNA library of I. pes-caprae with the salt-sensitive yeast mutant AXT3, in which three $\mathrm{Na}^{+}$transporter genes (ena1-4, nha1, and $n h x 1$ ) were functionally deleted. Although we did not obtain any salt ion transporter genes during the screening process, we did still isolate some salt-stress-related candidate genes from I. pes-caprae (Table 1). This can be reduced to two reasons: firstly, the quality of the I. pes-caprae cDNA library is not good enough to isolate more functional key salt tolerance genes, or a broader screening is still needed to obtain more functional genes; secondly, as a single-cell organism, the yeast cannot fully reflect the salt tolerance process in multicellular plants and especially cannot simulate ion translocation or exclusion during our screening assay. In any case, further functional characterization of some key candidate genes conferring salt tolerance isolated from this assay will be helpful for deepening our understanding of the molecular mechanisms of the osmotic stress response and should provide some excellent and operative functional genes for genetic improvements for stress tolerance in crops in the future.

Halophytes can thrive under high salinity by adopting two strategies, namely, salt tolerance and salt avoidance [8]. Generally, euhalophytes possess strong salinity tolerance due to succulence, enabling the storage of more salty ions [28]. Ipomoea pes-caprae is a common pantropical creeping vine plant with slight leaf succulence and obvious stem (or vine) succulence. In our research, the $\mathrm{Na}^{+}$ content in the leaves and vines of I. pes-caprae showed apparently higher levels than in the roots (Figure 1A), indicating that I. pes-caprae growing in saline land can absorb and store salt in aboveground tissues. This differs from crinohalophytes and pseudohalophytes, in which the salts are secreted to the surroundings or stored in the roots or some cortical tissues of the aerial parts [29]. Here, we chose I. pes-caprae as a candidate for identifying salt-stress-related genes, and it was speculated that in I. pes-caprae the cells are severely challenged by salt stresses; thus, the multifunctionality of the salt tolerance genes will be more direct and distinctive.

Numerous studies have been done to provide a better understanding of the high salinity tolerance mechanisms of halophytes, with the purpose of isolating some key functional salt tolerance genes allowing halophytes to grow and flourish in high-saline environments and to breed crops with better performance under salinity stress $[3,7,30]$. However, some molecular biologists have assumed that only basic biochemical tolerance mechanisms, mainly related to water deficiency and osmotic stress processes, may be sufficient to confer a response to salt [31]. Even though only osmotic stress may still trigger many primary responses, including morphological and developmental changes, adjustment in ion transport, and metabolic changes, some secondary stress signal transduction should occur in turn [32]. It is obvious that in halophytes some molecular regulation and responding systems exist that differ from those in glycophytes and which are involved in maintaining regular growth and metabolism of the plant under salt stress.

In general, corresponding to the three categories of salt tolerance mechanisms in plants, the HKT (high-affinity potassium transporter) genes and the SOS (salt overly sensitive) pathway mainly mediate in regulating $\mathrm{Na}^{+}$transport within ion exclusion processes in plants to limit the entry of salt via the roots; in plant tissue tolerance, vacuolar $\mathrm{Na}^{+} / \mathrm{H}^{+}$antiporters (NHX) or V-PPase/V-ATPase play roles in controlling ion concentration and distribution, or enzymes for the biosynthesis of compatible solutes and proteins for the detoxification of ROS play roles to different extents in improving crop salinity tolerance. As to the third one, osmotic tolerance, although there are no specific candidate genes responding to it, several categories of functional genes, such as ROS generation and detoxification pathways, osmoregulation or ion homeostasis, salt-responsive genes, and transcription factors, even some chaperones, have been proved to be coordinately linked with this stress sensing and 
signal transduction [3,30]. From the holistic perspective, the osmotic stress as a consequence of ion and water imbalance in the whole plant might also have a greater effect on crop growth than the ionic toxicity, especially at low to moderate salinity levels [3,4].

In plant cells, many environmental stresses induce the accumulation of ROS, which then results in the expression of a series of stress response genes [33]. It is also known that oxidative stress signaling and ROS detoxification are both essential components of salinity stress tolerance mechanisms in halophytes [6]. In this research, we focused on the crosstalk between ROS detoxification and salt tolerance by assessing gene expression regulation by salt stress, and determined seven candidate genes that are involved in the salt stress response. Following the work of Roy et al. [3] and Mishra et al. [30], we classified all of these genes into the category responding to osmotic stress tolerance, mainly by mediating the ROS detoxification and ion/water homeostasis. Plant genetic engineering and manipulation of these novel salt-stress-related genes from I. pes-caprae may facilitate the development of glycophytes, particularly crops, with improved salt tolerance, and in the future may hold great promise in improving agricultural productivity under high salinity and drought stress. Several important candidate genes involved in salt tolerance isolated in this assay are listed and discussed in the following subsections.

\subsection{Plant Abscisic Acid, Stress, and Ripening-Induced (ASR) Proteins}

In this research, we obtained a yeast clone containing IpASR cDNA encoding an abscisic acid stress ripening-related protein, which showed high amino acid identities with the Suaeda liaotungensis ASR protein SIASR (AGZ20206.1) [34] and the Salicornia brachiate ASR protein SbASR-1 (ACI15208.1) [35]. ASR proteins play biochemical roles not only as transcription factors, but also as chaperones [36,37], and a number of reports have indicated that ASR members are involved in the salt and drought stress response which is gaining increasing attention due to water shortage issues in agriculture. Homology analysis of different plant ASR proteins indicated that IpASR could play similar biological roles in responding to high salt and drought stress. In our research, IpASR could partly complement the salt-sensitive defect of the yeast mutant strain AXT3 (Figure 3), and could also elevate the salt tolerance of the wild yeast strain W303 (Figure 4). Further experiments in yeast strains yap $1 \Delta$ and $s k n 7 \triangle$ suggested that IPASR could also improve oxidation resistance in yeast (Figure 5). The expression of IpASR in I. pes-caprae seedlings was also obviously induced under salt ( $300 \mathrm{mM} \mathrm{NaCl})$ and osmotic stress (300 mM mannitol) challenges (Figure 6), which further indicated that IpASR might play pivotal roles in the adaptation of I. pes-caprae as a halophyte to extremely salty and dry environments.

\subsection{LEA Proteins}

Plant LEA proteins are hydrophilic and intrinsically disordered proteins which have been variously proposed to protect cellular structures from the effects of water loss by acting as a hydration buffer, by sequestering ions, by direct protection of other proteins or membranes, or by renaturing unfolded proteins [38]. Among them, dehydrins belong to group II LEA proteins, which are considered to be stress proteins involved in the formation of protective responses of plants to osmotic stress [39]. Many previous studies regarding the ectopic expression of individual LEA genes, including dehydrins, in various organisms have also provided support for functions in cellular protection under conditions of stress, including salinity, frost, and, in particular, drought $[40,41]$. In our study, yeast strains (AXT3 and W303) transformed with either a $L E A$ gene (IpLEA) or a dehydrin gene (IpDHN) cloned from I. pes-caprae subjected to salinity stress exhibited better survival than those with the empty vectors (Figures 3 and 4) and also exhibited an increased tolerance against the oxidant $\mathrm{H}_{2} \mathrm{O}_{2}$ in yap $1 \Delta$ and $s k n 7 \Delta$ (Figure 5), indicating that IPLEA and IpDHN could positively regulate salinity tolerance and mediate the response to oxidative stress. Our RT-PCR analysis showed obvious induced patterns under salt $(300 \mathrm{mM} \mathrm{NaCl})$ and osmotic stress (300 mM mannitol) challenges (Figure 6), suggesting possible cellular protective effects regulated by salinity and osmotic stress. The functions of IpLEA and IpDHN cloned from I. pes-caprae in regulating salinity tolerance deserve further consideration. 


\subsection{SNARE Proteins}

Soluble $\mathrm{N}$-ethylmaleimidesensitive fusion protein attachment protein receptors (SNARE) proteins constitute a type of membrane-anchored proteins that play key roles in vesicle-associated membrane fusion events during cellular vesicle trafficking between individual compartments of the endomembrane system, including exocytosis and endocytosis [42]. Considering that vesicle trafficking is a cellular housekeeping activity, SNARE may function in the spatial distribution of ion transporters that are important for plant development, as well as for ion detoxification caused by salt stress. Meanwhile, vesicle trafficking may also be influenced by the ion gradients they establish within the expanding cell [43]. Several reports have shown that over-expression of plant SNARE genes could improve the salt and drought tolerance of transgenic plants [44-46], which indicates that SNARE proteins might be involved in membrane stability, the $\mathrm{K}^{+} / \mathrm{Na}^{+}$ratio, and antioxidant machinery [45]. NCBI SmartBlast analysis revealed that the IpSNARE (IpSR14) protein has a high sequence identity ( $47 \%$ amino acid identity under $77 \%$ query cover) to a SNARE-like superfamily protein from $A$. thaliana (NP_567842.1; At4g30240). In our research, we speculated that IpSNARE might be involved in $\mathrm{Na}^{+}$and $\mathrm{H}_{2} \mathrm{O}_{2}$ redistribution in yeast by facilitating vesicle trafficking and improving the tolerance of yeast to salt and $\mathrm{H}_{2} \mathrm{O}_{2}$ (Figures 3-5). The expression of IpSNARE was also induced by salt and osmotic stress in vivo (Figure 6). The results suggest that IpSNARE could be a potential candidate gene for increasing salinity and drought tolerance in crop plants for sustainable agriculture in arid and/or saline soil.

\subsection{Catalase and Glutathione S-Transferase}

Halophytic adaptation to salt stress involves a series of biochemical pathways and many active compounds including antioxidant enzymes. Catalase and glutathione S-transferase are two types of antioxidant enzymes responsible for ROS scavenging in plants [47]. Catalases can directly detoxify $\mathrm{H}_{2} \mathrm{O}_{2}$ generated from photorespiratory pathways, and also can effectively relieve the restrained growth caused by salt or other abiotic stresses [48]. Although there is little evidence for the up-regulated expression of catalase genes in plants for improving salt tolerance, some studies involving the knock-out or knock-down of catalase genes have indicated that they play significant roles against salinity in plants [49]. A catalase gene from the cyanobacterium Anabaena, katB, was strongly induced in response to osmotic stress or desiccation, and inactivation of $k a t B$ resulted in enhanced sensitivity to salt stress in Anabaena cells [50]. Glutathione S-transferases (GSTs), as a type of detoxification enzyme, have versatile functions in multiple aspects of plant growth and development [51]. It has been confirmed that GSTs are induced by a variety of biotic and abiotic stresses [52]. Several plant glutathione transferase genes have been proved by plant transgenic assays mediating osmotic stress tolerance, mainly by ROS detoxification [53-56]. Here, we identified a catalase gene and a GST gene by functional screening with the I. pes-caprae cDNA library (Table 1), and there is little doubt that these two genes can improve the tolerance of yeast to $\mathrm{H}_{2} \mathrm{O}_{2}$ (Figure 5). RT-PCR analysis indicated that the expression patterns of the two genes challenged by salt and osmotic stress were both up-regulated (Figure 6), which further indicated that these two genes (IpSR18 and IpSR33, defined as IpCAT and IpGST, respectively) might be involved in osmotic and water deficit stresses by mediating ROS equilibrium. Furthermore, our study also implied that IpCAT and IpGST may be potential candidate genes to be used in genetic engineering for enhancing abiotic stress tolerance.

\subsection{Other Stress-Responsive Proteins}

We also identified some other possible stress-responsive genes, including I $p S R 3$ (nudix hydrolase), IpSR8 (endoplasmic reticulum vesicle transporter), IpSR10 and IpSR23 (proteasome inhibitors), IpSR19 (stress responsive alpha-beta barrel domain protein), and IpSR28 (dnaj protein-like protein) (Table 1). Since their homologous proteins in other species might mediate stress or hormone responses [57-61], future research on the functional identification of these genes should focus on their possible roles in abiotic stress. Of these, IpSR19, encoding a stress-responsive alpha-beta barrel domain protein, 
also named GLYCOLATE OXIDASE3 (UP3) in Arabidopsis, is a peroxisomal protein [62] that also showed oxidation resistance in yeast strains (Figure 5) and was up-regulated under salt and osmotic stress challenges (Figure 6). We proposed that the IpSR19 protein might also be involved in salt and drought tolerance by maintaining ROS equilibrium in I. pes-caprae.

To date, little genome information is available on I. pes-caprae, and no transcriptome and proteome data have been reported. Here, in this study, we adopted a cDNA library and screening strategy, the FOX hunting system, to obtain functional genes with full-length cDNAs responding to specific abiotic stresses within a short span of time. This approach may be particularly useful for the identification of some functional genes in wild plants lacking genetic information, and will be of great convenience for the elucidation of salt-tolerant or other stress-related genes. The FOX gene hunting approach was first proposed by Ichikawa T. et al. for the purpose of isolating functional genes in Arabidopsis that could result in a mutant phenotype via overexpression of the genes [63]. Subsequently, this technology has also been applied to rice with activation tags in a large generated rice population to identify useful traits and functional genes [14,64]. In Eutrema salsugineum (a halophyte, relative of Arabidopsis, also known as Thellungiella salsuginea and formerly Thellungiella halophila), two functional genes responding to salt or heat stress were also identified with the FOX hunting system $[65,66]$. Also, in another Brassicaceae halophytic relative of Arabidopsis, Lepidium crassifolium, the cDNA library was screened with the FOX hunting system in Arbidopsis, and the proteins GDSL-like lipase and Acyl CoA binding protein 6 were supposed to be involved in salt tolerance and osmotic stress tolerance, respectively [67]. After a decade of development, this strategy has been identified as a powerful tool for elucidating functional genomics and facilitating the discovery of useful genes in model plants or crops $[17,68,69]$ or digging useful candidate genes from some wild plants [65-67]. The functional screening and identification of genes by transgenic assays in plants is a time-consuming and costly process during the first course of cDNA library screening. A modified FOX gene hunting system has been applied with a central change in the screening method, that is, with functional identification in yeast instead of in a plant; in this way, the experimental cycle of FOX hunting was greatly reduced $[15,16,22]$. For some wild plants lacking any genetic information, the FOX gene hunting approach with a novel gain-of-function strategy showed a greater advantage in the once-off and wide acquisition of full-length cDNAs of functional genes in a short time. In this research, a modified FOX gene hunting system was applied, resulting in the identification of 38 full-length cDNAs encoding candidate salt tolerance genes from I. pes-caprae.

In summary, in this paper we described a highly efficient approach for isolating salt tolerance genes from I. pes-caprae based on a FOX gene hunting system for the large-scale screening of functional genes. A high-quality cDNA expression library was successfully constructed and 38 potential IpSRs were identified. Several known genes involved in salt tolerance also showed oxidation resistance in yeast, and the transcriptional expression levels were detected. Interestingly, our results indicated that several pathways might participate in the regulation of salt tolerance in I. pes-caprae, including those related to water deficit, ROS scavenging, and cellular vesicle trafficking. These results provide the first insight into the salt tolerance gene network in I. pes-caprae. However, the biochemical and molecular mechanisms regarding the manner in which these novel genes regulate salinity tolerance are unknown. Further analysis of these IpSRs could provide deeper insights into the survival mechanisms of halophytes in extreme environments, and the identified genes could then serve as useful targets for the genetic modification of glycophytic plants for improved stress tolerance.

\section{Materials and Methods}

\subsection{Plant Materials, Growth Conditions, and Stress Treatments}

The seeds and young plants of I. pes-caprae were harvested from August to October around the seaside of Huizhou city $\left(22^{\circ} 41^{\prime} 24.81^{\prime \prime} \mathrm{N}, 114^{\circ} 44^{\prime} 48.02^{\prime \prime}\right.$ E), Guangdong province. The young leaves and shoots were used to construct a cDNA library. For culturing the seedlings of I. pes-caprae, the seeds 
were sterilized with $70 \%$ ethanol followed by seed coat breaking with emery paper prior to placement onto MS basal salts distributed in plates with sand and soil collected outdoors from April to November in Guangzhou city. The seedlings were used for salt tolerance assays 30 days after germination. Subsequently, salt ( $300 \mathrm{mM} \mathrm{NaCl}$ ) and osmotic ( $300 \mathrm{mM}$ mannitol) stresses were applied to I. pes-caprae seedlings to detect the expression patterns of some candidate salt-tolerant genes. Experiments were performed following a completely randomized design with three replications and were repeated three times.

\subsection{Measurement of $\mathrm{Na}^{+}$and $\mathrm{K}^{+}$Contents in I. pes-caprae}

Whole plants of I. pes-caprae were harvested from four different beaches in Guangdong province, including Shenzhen $\left(22^{\circ} 32^{\prime} 13.16^{\prime \prime} \mathrm{N}, 114^{\circ} 29^{\prime} 11.26^{\prime \prime} \mathrm{E}\right)$, Huizhou $\left(22^{\circ} 41^{\prime} 24.81^{\prime \prime} \mathrm{N}, 114^{\circ} 44^{\prime} 48.02^{\prime \prime} \mathrm{E}\right)$, Yangjiang $\left(21^{\circ} 34^{\prime} 37.34^{\prime \prime} \mathrm{N}, 111^{\circ} 52^{\prime} 15.95^{\prime \prime} \mathrm{E}\right)$, and Shanwei $\left(22^{\circ} 47^{\prime} 10.97^{\prime \prime} \mathrm{N}, 115^{\circ} 10^{\prime} 22.83^{\prime \prime} \mathrm{E}\right)$; a sample series of I. pes-caprae growing in South China Botanical Garden $\left(23^{\circ} 18^{\prime} 49.89^{\prime \prime} \mathrm{N}, 113^{\circ} 35^{\prime} 84.32^{\prime \prime} \mathrm{E}\right)$ cultivated with freshwater and regular soil was used as a control, as well as adult Arabidopsis (ecotype: col-0) plants cultured in a greenhouse under regular conditions. The different tissues of I. pes-caprae collected from those five areas were separated into fibrous roots, old roots, vines, and leaves, and then each sample (about $10 \mathrm{~g}$ ) was cleaned with water and dried in a constant-temperature drying oven at $70{ }^{\circ} \mathrm{C}$; the whole Arabidopsis plants were treated with the same protocol. Dried samples were crushed by a vibrating and ball-mining mixed machine (GSM 06, Siebtechnik, Mülheim, Germany). About $0.2 \mathrm{~g}$ of sample powder (accurate to $0.0001 \mathrm{~g}$ ) was placed in a polytetrafluoroethylene tube and $6 \mathrm{~mL}$ of analytically pure concentrated nitric acid was added to each sample overnight at room temperature. The samples were then treated with a microwave digestion system according to the operating manual. Following microwave digestion, the sample liquids were transferred to new $50 \mathrm{~mL}$ volumetric flasks, diluted with $\mathrm{ddH}_{2} \mathrm{O}$ to a certain volume, and mixed. The contents of $\mathrm{Na}^{+}$and $\mathrm{K}^{+}$in the sample solutions were measured with a Perkin-Elmer inductively coupled plasma atomic absorption spectrometer. Each tissue sample was collected from three dependent adjacent plants in the same spot.

\section{3. cDNA Library Construction and Quality Examination Assays}

Total RNAs were extracted with TRIzol (Invitrogen, Thermo Fisher Scientific Inc., Waltham, MA, USA) and mRNAs were isolated from the total RNAs using the FastTrack ${ }^{\circledR}$ MAG mRNA Isolation Kit (Invitrogen, Thermo Fisher Scientific Inc., Waltham, MA, USA). The integrity and purity of total RNAs extracted from the plants was detected by $1 \%$ agarose gel electrophoresis and a Nucleic Acid Analyzer (NanoDrop 2000, Thermo Fisher Scientific Inc., USA), and purified mRNAs were subjected to the same analysis. The total mRNAs were reverse-transcribed to the cDNAs using a SMART cDNA Synthesis Kit (Clontech, Takara Bio, Dalian, China) according to the manufacturer's instructions. The cDNA libraries were constructed based on the Gateway ${ }^{\circledR}$ cloning technology (Invitrogen, Thermo Fisher Scientific Inc., USA). In brief, the double strand-cDNAs were cloned into the pDONR222 vector using $\mathrm{BP}$ reaction (Gateway ${ }^{\mathrm{TM}} \mathrm{BP}$ Clonase ${ }^{\mathrm{TM}} \mathrm{II}$ Enzyme, Invitrogen), and the entry clone library was obtained. Through the LR reaction (Gateway ${ }^{\mathrm{TM}}$ LR Clonase ${ }^{\mathrm{TM}}$ II Enzyme mix, Invitrogen) of the Gateway ${ }^{\circledR}$ cloning technology, the yeast expression vector PYES-DEST52 was ligated with the entry clone library to generate the secondary yeast expression library, in which the total I. pes-caprae cDNAs were inserted into the yeast expression cassette under the galactose-induced promoter pGAL1.

The mixtures of the BP and LR reactions containing an entry clone library and secondary expression library were introduced separately into competent cells of E. coli DH10B by electroporation. Thousand-fold diluted libraries were then cultured overnight on a solid medium plate (LB plus $50 \mathrm{mg} \mathrm{L}^{-1}$ kanamycin or $100 \mathrm{mg} \mathrm{L}^{-1}$ ampicillin) and the clones were counted. Twenty-four single clones of the two libraries were selected separately to obtain a monoclonal colony to detect the length of the inserted fragment of the libraries. The primer pairs for pDONR222 and pYES-DEST52 were $\mathrm{pD22F} / \mathrm{pD} 22 \mathrm{R}\left(5^{\prime}-3^{\prime}\right)$ : GTAAAACGACGGCCAGTC/CCAGGAAACAGCTATGAC and T7/pY52R 
$\left(5^{\prime}-3^{\prime}\right)$ : TAATACGACTCACTATAGGG/AGGGTTAGGGATAGGCTTACC. Fifty random clones in the secondary expression library were sequenced; thereafter, the start codon (ATG) was found following BLASTX analysis.

\subsection{Yeast Mutant Strains and Functional Screening}

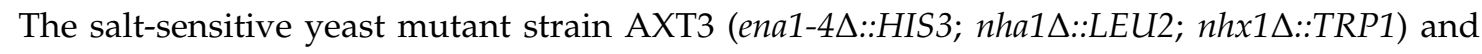
its wild-type strain W303 (MATa; his3-11_15; leu2-3_112; ura3-1; trp1 2 2; ade2-1; can1-100) were kindly provided by Pardo [24] and Jiang [25]. $\mathrm{H}_{2} \mathrm{O}_{2}$-sensitive mutant yeast strains yap1 $\Delta$ (Y00569,

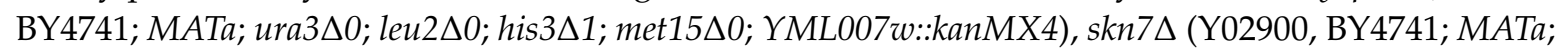
ura3 $\Delta 0$; leu2 $\Delta 0$; his3 $\Delta 1$; met15 $\Delta 0$; YHR206w::kanMX4) and their isogenic wild-type (WT) BY4741 (Y00000, MATa; his3 $\Delta 1$; leu2 $\Delta 0$; met15 $\Delta 0$; ura3 $\Delta 0$ ) were all obtained from Euroscarf (available online: http:/ / www.euroscarf.de/index.php?name=News).

The pYES-DEST52 cDNA expression library plasmids were separated using the SDS alkaline lysis method and then introduced into yeast strains via a polyethylene glycol (PEG)-lithium acetate-based transformation protocol [70] to screen the candidate stress-related functional genes. For the salt-sensitive mutant AXT3, the transformation products were plated on SDG-Ura solid medium (supplied with adenine) with $75 \mathrm{mM} \mathrm{NaCl}$ lacking uracil. The plates were placed at $30{ }^{\circ} \mathrm{C}$ for 3 to 7 days until single clones appeared. The plasmids from the surviving yeast clones were rescued in E. coli and extracted. About 100 plasmids in total were selected and sequenced with an automatic sequencing machine (ABI, Columbia, MD, USA). The plasmids containing the candidate cDNAs were also introduced into different yeast stains to perform the function verification, based on the same transformation protocol [70]. The basal SDG (Synthetic Dropout-/Galactose) medium was made with $1.7 \mathrm{~g} \mathrm{~L}^{-1}$ Yeast Nitrogen Base (YNB powder, BD Difco ${ }^{\mathrm{TM}}$, Bergen County, NJ, USA), $5 \mathrm{~g} \mathrm{~L}^{-1}$ ammonium sulfate, and $20 \mathrm{~g} \mathrm{~L}^{-1}$ galactose, with a $\mathrm{pH}$ value of 7.5.

\subsection{Salt and $\mathrm{H}_{2} \mathrm{O}_{2}$ Sensitivity Assays in Yeast Cells}

Following sequence confirmation of the plasmids isolated from the surviving yeast clones, the plasmids containing I. pes-caprae cDNAs were then transformed into yeast cells following Gietz

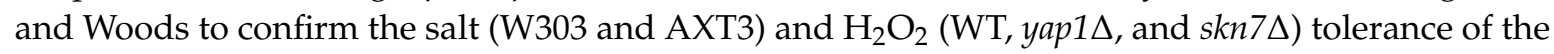
candidate functional genes isolated from the cDNA library. In general, yeast transformants were precultured in SDG-Ura medium overnight at $30^{\circ} \mathrm{C}$, diluted with fresh prewarmed SDG-Ura medium, and then incubated with vigorous shaking for about $48 \mathrm{~h}$ at $30^{\circ} \mathrm{C}$ to reach an optical density of just over 2.0 at OD600. Then, the cells were serially diluted in 10-fold steps, and $2 \mu \mathrm{L}$ aliquots of each were finally spotted onto SDG-Ura agar medium with or without $\mathrm{NaCl}$ or $\mathrm{H}_{2} \mathrm{O}_{2}$. The $\mathrm{NaCl}$ concentrations used were 50, 75, and $200 \mathrm{mM}$ for salt tolerance with the AXT3 yeast strain, or $0.85 \mathrm{M}$ (mass-to-volume $5 \%$ ), $1.28 \mathrm{M}$ (mass-to-volume 7.5\%), and $1.5 \mathrm{M}$ (mass-to-volume $8.8 \%$ ) $\mathrm{NaCl}$ separately for salt tolerance with the wild-type yeast strain $\mathrm{W} 303$. The $\mathrm{H}_{2} \mathrm{O}_{2}$ concentrations were 0.25 and $0.5 \mathrm{mM}$ for the antioxidative assay with yeast strain WT (wild-type BY4741), yap1 $\Delta$, and $s k n 7 \Delta$. The test plates were incubated at $30{ }^{\circ} \mathrm{C}$ for 3 to 7 days.

\subsection{Quantitative Reverse Transcription ( $q R T)-P C R$ Analysis}

According to the sequences of the cDNAs screened from the cDNA library of I. pes-caprae, the qRT-PCR primer pairs were designed using the online program for Primer-BLAST with the following parameters: Tm of approximately $60^{\circ} \mathrm{C}$ and product size range of $90-250 \mathrm{bp}$ (available online: https:/ / www.ncbi.nlm.nih.gov/tools/primer-blast/index.cgi?LINK_LOC=BlastHome). The partial cDNA sequence of the reference gene (IpUBQ) was cloned from I. pes-caprae and submitted to GenBank (accession number: MF502417), and was used as an internal control to normalize the amount of total cDNA present in each reaction. The primer sequences used for qRT-PCR analysis are listed in Supplementary Data Table S4. Generally, total RNAs were isolated with the HiPure Plant RNA Kit (Magen, Guangzhou, China) from the leaves, vines, and roots of I. pes-caprae seedlings according to the 
manufacturer's instructions. Three parallel experiments were carried out to enable the assessment of significance. After assessing the concentration using a NanoDrop 2000 (Thermo Fisher Scientific Inc., USA), first strand cDNAs were synthesized by adopting TransScript One-Step gDNA Removal and cDNA Synthesis SuperMix (TransGen Biotech, Beijing, China) from $1 \mu \mathrm{g}$ total RNA according to the manufacturer's instructions. RT-PCR was conducted using a model 7500 Real-Time PCR system (Applied Biosystems, Thermo Fisher Scientific Inc., USA) and TransStart Tip Green qPCR SuperMix (TransGen Biotech, Beijing, China).

\subsection{Statistical Analysis}

All experiments were repeated at least three times in independent experiments, and the plant samples of independent experiments were harvested from at least five seedlings per treatment. The data analysis was performed using the statistical tools (Student's $t$-test) of Excel 2010 (Microsoft, Seattle, WA, USA).

Supplementary Materials: Supplementary materials can be found at http:/ /www.mdpi.com/1422-0067/19/11/ 3446/s1.

Author Contributions: Conceptualization, S.-G.J., M.Z., K.-F.X.; Data curation, M.Z., H.Z., J.-X.Z. and H.M.; Formal analysis, M.Z., H.Z.; Funding acquisition, S.-G.J., M.Z., K.-F.X.; Methodology, M.Z., H.Z. and J.-X.Z.; Project administration, M.Z. and K.-F.X.; Supervision, S.-G.J. and M.Z.; Writing一original draft, M.Z.; Writing一review \& editing, M.Z., S.-G.J.

Funding: This research was supported by grants from the National Key Research and Development Program of China (2016YFC1403002), the "Strategic Priority Research Program" of the Chinese Academy of Sciences (XDA13020500), and "the Twelfth Five-Year" National S\&T Projects for Rural Areas (2015BAL04B04). The funders had no roles in the study design, data collection and analysis, decision to publish, or preparation of the manuscript.

Acknowledgments: We would like to thank Xing-Yu Jiang (Hainan University), Yang Zhou (Hainan University), and José M. Pardo (Instituto de Recursos Naturales y Agrobiología, C.S.I.C.) for providing yeast strains AXT3 and W303. Thanks are also given to several anonymous reviewers for their constructive comments and suggestions to improve this manuscript.

Conflicts of Interest: The authors declare no conflict of interest.

\section{Abbreviations}

$\begin{array}{ll}\text { FOX } & \text { Full-length cDNA Over-eXpressor } \\ \text { SR } & \text { Salt-stress Related } \\ \text { qRT-PCR } & \text { Quantitative Reverse Transcript-Polymerase Chain Reaction } \\ \text { ROS } & \text { Reactive Oxygen Species } \\ \text { SCBG } & \text { South China Botanical Garden } \\ \text { NCBI } & \text { National Center for Biotechnology Information } \\ \text { RIN } & \text { RNA Integrity Number } \\ \text { ORF } & \text { Open Reading Frame } \\ \text { LB } & \text { Luria-Bertani } \\ \text { MS } & \text { Murashige and Skoog } \\ \text { SDG } & \text { Synthetic Dropout/Galactose } \\ \text { OX } & \text { Over eXpression }\end{array}$

\section{References}

1. Shabala, S. Learning from halophytes: Physiological basis and strategies to improve abiotic stress tolerance in crops. Ann. Bot. 2013, 112, 1209-1221. [CrossRef] [PubMed]

2. Deinlein, U.; Stephan, A.B.; Horie, T.; Luo, W.; Xu, G.; Schroeder, J.I. Plant salt-tolerance mechanisms. Trends Plant Sci. 2014, 19, 371-379. [CrossRef] [PubMed]

3. Roy, S.J.; Negrão, S.; Tester, M. Salt resistant crop plants. Curr. Opin. Biotechnol. 2014, 26, 115-124. [CrossRef] [PubMed]

4. Munns, R.; Tester, M. Mechanisms of salinity tolerance. Annu. Rev. Plant Biol. 2008, 59, 651-681. [CrossRef] [PubMed] 
5. Zhu, J.K. Salt and drought stress signal transduction in plants. Annu. Rev. Plant Biol. 2002, 53, $247-273$. [CrossRef] [PubMed]

6. Bose, J.; Rodrigo-Moreno, A.; Shabala, S. ROS homeostasis in halophytes in the context of salinity stress tolerance. J. Exp. Bot. 2014, 65, 1241-1257. [CrossRef] [PubMed]

7. Kumari, A.; Das, P.; Parida, A.K.; Agarwal, P.K. Proteomics, metabolomics, and ionomics perspectives of salinity tolerance in halophytes. Front. Plant Sci. 2015, 6, 537. [CrossRef] [PubMed]

8. Flowers, T.J.; Colmer, T.D. Plant salt tolerance: Adaptations in halophytes. Ann. Bot. 2015, 115, 327-331. [CrossRef] [PubMed]

9. Devall, M.S; Thien, L.B. Factors influencing the reproductive success of Ipomoea pes-caprae (Convolvulaceae) around the gulf of Mexico. Am. J. Bot. 1989, 76, 1821-1831. [CrossRef]

10. Miryeganeh, M.; Takayama, K.; Tateishi, Y.; Kajita, T. Long-distance dispersal by sea-drifted seeds has maintained the global distribution of Ipomoea pes-caprae subsp. brasiliensis (Convolvulaceae). PLoS ONE 2014, 9, e91836. [CrossRef] [PubMed]

11. Ouyang, P.Y.; Liu, N.; Zhang, W.W.; Wang, J.; Jian, S.G. Biological and ecophysiological characteristics of a beach plant Ipomoea pes-caprae. J. Hunan Univ. Sci. Technol. (Nat. Sci. Ed.) 2011, 26, 117-121.

12. Urano, K.; Kurihara, Y.; Seki, M.; Shinozaki, K. 'Omics' analyses of regulatory networks in plant abiotic stress responses. Curr. Opin. Plant. Biol. 2010, 3, 132-138. [CrossRef] [PubMed]

13. Higuchi-Takeuchi, M.; Kondou, Y.; Ichikawa, T.; Matsui, M. Full-length cDNA overexpressor gene hunting system (FOX hunting system). Methods Mol. Biol. 2011, 678, 77-89.

14. Sakurai, T.; Kondou, Y.; Akiyama, K.; Kurotani, A.; Higuchi, M.; Ichikawa, T.; Kuroda, H.; Kusano, M.; Mori, M.; Saitou, T.; et al. RiceFOX: A database of Arabidopsis mutant lines overexpressing rice full-length cDNA that contains a wide range of trait information to facilitate analysis of gene function. Plant Cell Physiol. 2011, 52, 265-273. [CrossRef] [PubMed]

15. Chen, Y.; Zong, J.; Tan, Z.; Li, L.; Hu, B.; Chen, C.; Chen, J.; Liu, J. Systematic mining of salt-tolerant genes in halophyte-Zoysia matrella through cDNA expression library screening. Plant Physiol. Biochem. 2015, 89, 44-52. [CrossRef] [PubMed]

16. Chen, Y.; Chen, C.; Tan, Z.; Liu, J.; Zhuang, L.; Yang, Z.; Huang, B. Functional identification and characterization of genes cloned from halophyte seashore paspalum conferring salinity and cadmium tolerance. Front. Plant Sci. 2016, 7, 102. [CrossRef] [PubMed]

17. Li, X.; Huang, L.; Lu, J.; Cheng, Y.; You, Q.; Wang, L.; Song, X.; Zhou, X.; Jiao, Y. Large-scale investigation of soybean gene functions by overexpressing a full-Length soybean cDNA library in Arabidopsis. Front. Plant Sci. 2018, 9, 631. [CrossRef] [PubMed]

18. Lippuner, V.; Cyert, M.S.; Gasser, C.S. Two classes of plant cDNA clones differentially complement yeast calcineurin mutants and increase salt tolerance of wild-type yeast. J. Biol. Chem. 1996, 271, 12859-12866. [CrossRef] [PubMed]

19. Piao, H.L.; Pih, K.T.; Lim, J.H.; Kang, S.G.; Jin, J.B.; Kim, S.H.; Hwang, I. An Arabidopsis GSK3/shaggy-like gene that complements yeast salt stress-sensitive mutants is induced by $\mathrm{NaCl}$ and abscisic acid. Plant Physiol. 1999, 119, 1527-1534. [CrossRef] [PubMed]

20. Matsumoto, T.K.; Pardo, J.M.; Takeda, S.; Bressan, R.A.; Hasegawa, P.M. Tobacco and Arabidiopsis SLT1 mediate salt tolerance of yeast. Plant Mol. Biol. 2001, 45, 489-500. [CrossRef] [PubMed]

21. Obata, T.; Kitamoto, H.K.; Nakamura, A.; Fukuda, A.; Tanaka, Y. Rice shaker potassium channel OsKAT1 confers tolerance to salinity stress on yeast and rice cells. Plant Physiol. 2007, 144, 1978-1985. [CrossRef] [PubMed]

22. Yu, G.; Li, J.; Sun, X.; Liu, Y.; Wang, X.; Zhang, H.; Pan, H. Exploration for the salinity tolerance-related genes from xero-halophyte Atriplex canescens exploiting yeast functional screening system. Int. J. Mol. Sci. 2017, 18, E2444. [CrossRef] [PubMed]

23. Kamakura, M.; Furukawa, A. Compensatory function for water transport by adventitious roots of Ipomoea pes-caprae. J. Plant Res. 2009, 122, 327-333. [CrossRef] [PubMed]

24. Quintero, F.J.; Blatt, M.R.; Pardo, J.M. Functional conservation between yeast and plant endosomal $\mathrm{Na}^{+} / \mathrm{H}^{+}$ antiporters. FEBS Lett. 2000, 471, 224-228. [CrossRef]

25. Zhou, Y.; Yin, X.; Duan, R.; Hao, G.; Guo, J.; Jiang, X. SpAHA1 and SpSOS1 coordinate in transgenic yeast to improve salt tolerance. PLoS ONE 2015, 10, e0137447. [CrossRef] [PubMed] 
26. Bienert, G.P.; Møller, A.L.; Kristiansen, K.A.; Schulz, A.; Møller, I.M.; Schjoerring, J.K.; Jahn, T.P. Specific aquaporins facilitate the diffusion of hydrogen peroxide across membranes. J. Biol. Chem. 2007, 282, 1183-1192. [CrossRef] [PubMed]

27. Ventura, Y.; Eshel, A.; Pasternak, D.; Sagi, M. The development of halophyte-based agriculture: Past and present. Ann. Bot. 2015, 115, 529-540. [CrossRef] [PubMed]

28. Reimann, C.; Breckle, S.W. Salt tolerance and ion relations of Salsola kali L.: Differences between ssp. tragus (L.) Nyman and ssp. ruthenica (Iljin) Soó. New Phytol. 1995, 130, 37-45. [CrossRef]

29. Glenn, E.P.; Brown, J.J.; Blumwald, E. Salt tolerance and crop potential of halophytes. CRC Crit. Rev. Plant Sci. 1999, 18, 227-255. [CrossRef]

30. Mishra, A.; Tanna, B. Halophytes: Potential resources for salt stress tolerance genes and promoters. Front. Plant Sci. 2017, 8, 829. [CrossRef] [PubMed]

31. Zhu, J.K.; Hasegawa, P.M.; Bressan, R.A. Molecular aspects of osmotic stress in plants. CRC Crit. Rev. Plant Sci. 1997, 16, 253-277. [CrossRef]

32. Xiong, L.; Zhu, J.K. Molecular and genetic aspects of plant responses to osmotic stress. Plant Cell Environ. 2002, 25, 131-139. [CrossRef] [PubMed]

33. You, J.; Chan, Z. ROS regulation during abiotic stress responses in crop plants. Front. Plant Sci. 2015, 6, 1092. [CrossRef] [PubMed]

34. Hu, Y.X.; Yang, X.; Li, X.L.; Yu, X.D.; Li, Q.L. The SlASR gene cloned from the extreme halophyte Suaeda liaotungensis K. enhances abiotic stress tolerance in transgenic Arabidopsis thaliana. Gene 2014, 549, $243-251$. [CrossRef] [PubMed]

35. Jha, B.; Lal, S.; Tiwari, V.; Yadav, S.K.; Agarwal, P.K. The SbASR-1 gene cloned from an extreme halophyte Salicornia brachiata enhances salt tolerance in transgenic tobacco. Mar. Biotechnol. (NY) 2012, 14, 782-792. [CrossRef] [PubMed]

36. Dominguez, P.G.; Carrari, F. ASR1 transcription factor and its role in metabolism. Plant Signal. Behav. 2015, 10, e992751. [CrossRef] [PubMed]

37. Shkolnik, D.; Bar-Zvi, D. Tomato ASR1 abrogates the response to abscisic acid and glucose in Arabidopsis by competing with ABI4 for DNA binding. Plant Biotechnol. J. 2008, 6, 368-378. [CrossRef] [PubMed]

38. Candat, A.; Paszkiewicz, G.; Neveu, M.; Gautier, R.; Logan, D.C.; Avelange-Macherel, M.H.; Macherel, D. The ubiquitous distribution of late embryogenesis abundant proteins across cell compartments in Arabidopsis offers tailored protection against abiotic stress. Plant Cell 2014, 26, 3148-3166. [CrossRef] [PubMed]

39. Liu, Y.; Song, Q.; Li, D.; Yang, X.; Li, D. Multifunctional roles of plant dehydrins in response to environmental stresses. Front. Plant Sci. 2017, 8, 1018. [CrossRef] [PubMed]

40. Hincha, D.K.; Thalhammer, A. LEA proteins: IDPs with versatile functions in cellular dehydration tolerance. Biochem. Soc. Trans. 2012, 40, 1000-1003. [CrossRef] [PubMed]

41. Kosová, K.; Vítámvás, P.; Prášil, I.T. Wheat and barley dehydrins under cold, drought, and salinity-What can LEA-II proteins tell us about plant stress response? Front. Plant Sci. 2014, 5, 343. [CrossRef] [PubMed]

42. Pratelli, R.; Sutter, J.U.; Blatt, M.R. A new catch in the SNARE. Trends Plant Sci. 2004, 9, 187-195. [CrossRef] [PubMed]

43. Grefen, C.; Blatt, M.R. SNAREs-molecular governors in signalling and development. Curr. Opin. Plant Biol. 2008, 11, 600-609. [CrossRef] [PubMed]

44. Tarte, V.N.; Seok, H.Y.; Woo, D.H.; Le, D.H.; Tran, H.T.; Baik, J.W.; Kang, I.S.; Lee, S.Y.; Chung, T.; Moon, Y.H. Arabidopsis Qc-SNARE gene AtSFT12 is involved in salt and osmotic stress responses and $\mathrm{Na}^{+}$accumulation in vacuoles. Plant Cell Rep. 2015, 34, 1127-1138. [CrossRef] [PubMed]

45. Singh, D.; Yadav, N.S.; Tiwari, V.; Agarwal, P.K.; Jha, B. A SNARE-Like superfamily protein SbSLSP from the halophyte Salicornia brachiata confers salt and drought tolerance by maintaining membrane stability, $\mathrm{K}^{+} / \mathrm{Na}^{+}$ ratio, and antioxidant machinery. Front. Plant Sci. 2016, 7, 737. [CrossRef] [PubMed]

46. Nisa, Z.U.; Mallano, A.I.; Yu, Y.; Chen, C.; Duan, X.; Amanullah, S.; Kousar, A.; Baloch, A.W.; Sun, X.; Tabys, D.; et al. GsSNAP33, a novel glycine soja SNAP25-type protein gene: Improvement of plant salt and drought tolerances in transgenic Arabidopsis thaliana. Plant Physiol. Biochem. 2017, 119, 9-20. [CrossRef] [PubMed]

47. Gill, S.S.; Tuteja, N. Reactive oxygen species and antioxidant machinery in abiotic stress tolerance in crop plants. Plant Physiol. Biochem. 2010, 48, 909-930. [CrossRef] [PubMed] 
48. Sofo, A.; Scopa, A.; Nuzzaci, M.; Vitti, A. Ascorbate peroxidase and catalase activities and their genetic regulation in plants subjected to drought and salinity stresses. Int. J. Mol. Sci. 2015, 16, 13561-13578. [CrossRef] [PubMed]

49. Mhamdi, A.; Queval, G.; Chaouch, S.; Vanderauwera, S.; Van Breusegem, F.; Noctor, G. Catalase function in plants: A focus on Arabidopsis mutants as stress-mimic models. J. Exp. Bot. 2010, 61, 4197-4220. [CrossRef] [PubMed]

50. Chakravarty, D.; Banerjee, M.; Bihani, S.C.; Ballal, A. A salt-inducible Mn-catalase (KatB) protects cyanobacterium from oxidative stress. Plant Physiol. 2016, 170, 761-773. [CrossRef] [PubMed]

51. Dong, Y.; Li, C.; Zhang, Y.; He, Q.; Daud, M.K.; Chen, J.; Zhu, S. Glutathione S-transferase gene family in Gossypium raimondii and G. arboreum: Comparative genomic study and their expression under salt stress. Front. Plant Sci. 2016, 7, 139. [CrossRef] [PubMed]

52. Dixon, D.P.; Cummins, I.; Cole, D.J.; Edwards, R. Glutathione-mediated detoxification systems in plants. Curr. Opin. Plant Biol. 1998, 1, 258-266. [CrossRef]

53. Jha, B.; Sharma, A.; Mishra, A. Expression of SbGSTU (tau class glutathione S-transferase) gene isolated from Salicornia brachiata in tobacco for salt tolerance. Mol. Biol. Rep. 2011, 38, 4823-4832. [CrossRef] [PubMed]

54. Kumar, S.; Asif, M.H.; Chakrabarty, D.; Tripathi, R.D.; Dubey, R.S.; Trivedi, P.K. Expression of a rice Lambda class of glutathione S-transferase, OsGSTL2, in Arabidopsis provides tolerance to heavy metal and other abiotic stresses. J. Hazard Mater. 2013, 248-249, 228-237. [CrossRef] [PubMed]

55. Chan, C.; Lam, H.M. A putative lambda class glutathione S-transferase enhances plant survival under salinity stress. Plant Cell Physiol. 2014, 55, 570-579. [CrossRef] [PubMed]

56. Xu, J.; Xing, X.J.; Tian, Y.S.; Peng, R.H.; Xue, Y.; Zhao, W.; Yao, Q.H. Transgenic Arabidopsis plants expressing tomato glutathione S-transferase showed enhanced resistance to salt and drought stress. PLoS ONE 2015, 10, e0136960. [CrossRef] [PubMed]

57. Ogawa, T.; Muramoto, K.; Takada, R.; Nakagawa, S.; Shigeoka, S.; Yoshimura, K. Modulation of NADH levels by Arabidopsis nudix hydrolases, AtNUDX6 and 7, and the respective proteins themselves play distinct roles in the regulation of various cellular responses involved in biotic/abiotic stresses. Plant Cell Physiol. 2016, 57, 1295-1308. [CrossRef] [PubMed]

58. Hong, S.H.; Chang, S.H.; Cho, K.C.; Kim, S.; Park, S.; Lee, A.Y.; Jiang, H.L.; Kim, H.J.; Lee, S.; Yu, K.N.; et al. Endoplasmic reticulum-Golgi intermediate compartment protein 3 knockdown suppresses lung cancer through endoplasmic reticulum stress-induced autophagy. Oncotarget 2016, 7, 65335-65347. [CrossRef] [PubMed]

59. Yang, B.J.; Han, X.X.; Yin, L.L.; Xing, M.Q.; Xu, Z.H.; Xue, H.W. Arabidopsis PROTEASOME REGULATOR1 is required for auxin-mediated suppression of proteasome activity and regulates auxin signalling. Nat. Commun. 2016, 7, 11388. [CrossRef] [PubMed]

60. Salas-Muñoz, S.; Rodríguez-Hernández, A.A.; Ortega-Amaro, M.A.; Salazar-Badillo, F.B.; Jiménez-Bremont, J.F. Arabidopsis AtDjA3 null mutant shows increased sensitivity to abscisic acid, salt, and osmotic stress in germination and post-germination stages. Front. Plant Sci. 2016, 7, 220. [CrossRef] [PubMed]

61. Engqvist, M.K.; Schmitz, J.; Gertzmann, A.; Florian, A.; Jaspert, N.; Arif, M.; Balazadeh, S.; Mueller-Roeber, B.; Fernie, A.R.; Maurino, V.G. GLYCOLATE OXIDASE3, a glycolate oxidase homolog of yeast 1-Lactate cytochrome c oxidoreductase, supports 1-Lactate oxidation in roots of Arabidopsis. Plant Physiol. 2015, 169, 1042-1061. [CrossRef] [PubMed]

62. Quan, S.; Yang, P.; Cassin-Ross, G.; Kaur, N.; Switzenberg, R.; Aung, K.; Li, J.; Hu, J. Proteome analysis of peroxisomes from etiolated Arabidopsis seedlings identifies a peroxisomal protease involved in $\beta$-oxidation and development. Plant Physiol. 2013, 163, 1518-1538. [CrossRef] [PubMed]

63. Ichikawa, T.; Nakazawa, M.; Kawashima, M.; Iizumi, H.; Kuroda, H.; Kondou, Y.; Tsuhara, Y.; Suzuki, K.; Ishikawa, A.; Seki, M.; et al. The FOX hunting system: An alternative gain-of-function gene hunting technique. Plant J. 2006, 48, 974-985. [CrossRef] [PubMed]

64. Nakamura, H.; Hakata, M.; Amano, K.; Miyao, A.; Toki, N.; Kajikawa, M.; Pang, J.; Higashi, N.; Ando, S.; Toki, S.; et al. A genome-wide gain-of function analysis of rice genes using the FOX-hunting system. Plant Mol. Biol. 2007, 65, 357-371. [CrossRef] [PubMed] 
65. Higashi, Y.; Ohama, N.; Ishikawa, T.; Katori, T.; Shimura, A.; Kusakabe, K.; Yamaguchi-Shinozaki, K.; Ishida, J.; Tanaka, M.; Seki, M.; et al. HsfA1d, a protein identified via FOX hunting using Thellungiella salsuginea cDNAs improves heat tolerance by regulating heat-stress-responsive gene expression. Mol. Plant 2013, 6, 411-422. [CrossRef] [PubMed]

66. Ariga, H.; Tanaka, T.; Ono, H.; Sakata, Y.; Hayashi, T.; Taji, T. CSP41b, a protein identified via FOX hunting using Eutrema salsugineum cDNAs, improves heat and salinity stress tolerance in transgenic Arabidopsis thaliana. Biochem. Biophys. Res. Commun. 2015, 464, 318-323. [CrossRef] [PubMed]

67. Rigó, G.; Valkai, I.; Faragó, D.; Kiss, E.; Van Houdt, S.; Van de Steene, N.; Hannah, M.A.; Szabados, L. Gene mining in halophytes: Functional identification of stress tolerance genes in Lepidium crassifolium. Plant Cell Environ. 2016, 39, 2074-2084. [CrossRef] [PubMed]

68. Higuchi-Takeuchi, M.; Matsui, M. Screening for gene function using the FOX (full-length cDNA overexpressor gene) hunting system. Methods Mol. Biol. 2014, 1056, 201-210. [PubMed]

69. Abe, K.; Ichikawa, H. Gene overexpression resources in cereals for functional genomics and discovery of useful genes. Front. Plant Sci. 2016, 7, 1359. [CrossRef] [PubMed]

70. Gietz, R.D.; Woods, R.A. Transformation of yeast by the LiAc/SS carrier DNA/PEG method. Methods Mol. Biol. 2006, 313, 107-120. [PubMed]

(C) 2018 by the authors. Licensee MDPI, Basel, Switzerland. This article is an open access article distributed under the terms and conditions of the Creative Commons Attribution (CC BY) license (http:/ / creativecommons.org/licenses/by/4.0/). 